\title{
POSSIBILITIES TO RECYCLE AUTO GLASS WASTE IN BUILDING CERAMICS
}

\author{
Jurgita Malaiškienė, Romualdas Mačiulaitis, Raminta Mikalauskaitė \\ Department of Building Materials, Vilnius Gediminas Technical University, \\ Saulètekio al. 11, 10223 Vilnius, Lithuania
}

Submitted 22 Feb. 2013; accepted 18 Nov. 2013

\begin{abstract}
Substantial amounts of glass waste end up in landfills because unlike ordinary glass, auto glass is unsuitable for recycling in the glass industry due to organic additives. However, it was determined that the additives make auto glass waste appropriate for the production of building ceramics, which results in improved physical-mechanical and structural properties. The optimum quantity of the additive contained in auto glass waste amounts to $15 \%$ of the formation mixture, and the most appropriate burning temperature is $1080{ }^{\circ} \mathrm{C}$. The density of such ceramic chip is $2059 \mathrm{~kg} / \mathrm{m}^{3}$, the water absorption determined after $72 \mathrm{~h}$ is $1.2 \%$, and the forecasted frost resistance at the beginning of decomposition is 1343 cycles, but amounts to 2188 cycles at the end of decomposition.
\end{abstract}

Keywords: pollution, auto glass waste, recycling, ceramics, physical-mechanical and structural properties, forecasted frost resistance.

Reference to this paper should be made as follows: Malaiškienè, J.; Mačiulaitis, R.; Mikalauskaite, R. 2014. Possibilities to recycle auto glass waste in building ceramics, Journal of Environmental Engineering and Landscape Management 22(1): 21-29. http://dx.doi.org/10.3846/16486897.2013.867863

\section{Introduction}

Approx. 28.5 million tonnes of glass are recycled in the European Union annually (Uselyte et al. 2007). Substantial amounts of glass waste end up in landfills. Unlike ordinary glass, auto glass is unsuitable for recycling in the glass industry due to organic additives. The recycling of auto glass into building materials offers environmentally friendly solutions. In the middle layer between glass sheets, auto glass contains small amounts of polymer structures.

Glass can be recycled but not PVB. The main material used in glass lamination is polyvinyl butyral (PVB), which burns out at approximately $450{ }^{\circ} \mathrm{C}$. It is a disposable by-product of the glass recycling industry available in quantity with no additional collection charges. Recycling by mechanical means is an alternative to landfilling. However, it is important to appreciate the variation in molecular structure of PVB and its effect on material properties and the end use (Dhaliwal, Hay 2002). The recycling problem was examined by Russian scientists (Gorokhovsky et al. 2005) focusing on the reuse of glass waste containing PVB. Tensile strength of PVB is $28-$ 59.5 MPa, compressive strength is $80-140 \mathrm{MPa}$. PVB has good adhesion to different materials as well as good optical properties (colourlessness, resistance to light, translucence) and resistance to atmospheric agents. However, it disperses into water and butyraldehyde at a temperature higher than $160{ }^{\circ} \mathrm{C}$ (Kabanov et al. 1974).

Experiments (Jaw et al. 2001) proved that the binder system composite with polyvinyl butyral would show good thermal behaviour in ceramic processing and the binder system would burnout at a considerably low temperature. Moreover, this effect is advantageous for the binder burnout procedure and ensures easy removal of binder. According to researchers (Seo et al. 1997), PVB could be used as a binder in ceramic processing, because it burns out at $500{ }^{\circ} \mathrm{C}$. Concentrations of hazardous substances are present in low concentrations; therefore, amounts emitted during the process of burning stay below the limits established by hygiene standards.

Recycling of various types of waste should be one of the most important contemporary issues. Many

Corresponding author: Jurgita Malaiškienè

E-mail: jurgita.malaiskiene@vgtu.lt 
researchers describe possible uses of waste in the industry of building materials. The studies are carried out using the production waste of mineral or mullite wool, fly ash, crushed glass, waste of paper manufacturing, etc.

These works (Kourti et al. 2010; Roether et al. 2010) demonstrated, that air pollution control residues can be used as the raw material for the production of glass-ceramics or novel geopolymer-glass composites with excellent mechanical and physical properties.

Researchers (Chiang et al. 2010) investigated ecobricks manufactured using water treatment plant (WTP) sludge and scrap glass. Materials containing from $20 \%$ of scrap glass and sintered at $1000{ }^{\circ} \mathrm{C}$ demonstrate low water absorption and relatively high compressive strength. These results confirm the feasibility of using scrap glass and WTP sludge to produce sintered construction eco-bricks.

Disposal of PC monitors and TV sets is a growing problem, as over $40 \%$ of their weight is comprised of waste glasses with high $\mathrm{Pb}$ or $\mathrm{Ba}-\mathrm{Sr}$ concentrations. This makes them unsuitable for recycling and manufacturing of new glass. A possible way to reuse these types of glass is for manufacturing of clay bricks and roof tiles. No significant release of $\mathrm{Pb}, \mathrm{Ba}$, and $\mathrm{Sr}$ was observed during firing and leaching test for the carbonate-poor body; in contrast, some $\mathrm{Pb}$ volatilization during firing and $\mathrm{Sr}$ leaching was observed for the carbonate-rich body. According to authors (Dondi et al. 2009), the main constraint is that the glass must have a particle size below the limit of the pan mills used in brickmaking $(<1 \mathrm{~mm})$.

The use of waste was investigated by scientists from China (Lin et al. 2012). Their research involved the effect of solar panel waste glass on fired clay bricks. Brick samples were heated to temperatures varying from 700 to $1000{ }^{\circ} \mathrm{C}$ for $6 \mathrm{~h}$. Solar panel waste glass brick contained $30 \%$ of solar panel waste glass and was sintered at $1000{ }^{\circ} \mathrm{C}$; the addition of solar panel waste glass to the mixture reduced the degree of firing shrinkage. The salt crystallization test and wet-dry tests showed that the addition of solar panel waste glass had highly beneficial effects in increasing the durability of bricks. This indicates that solar panel waste glass is indeed suitable for partial replacement of clay in bricks.

In the researches on building ceramics, crushed glass made from windows and bottles is often used (Angjusheva 2011; Pavlushkina, Kisilenko 2011). It was determined that in terms of the beginning of decomposition, the expected frost resistance of samples containing $\leq 5 \%$ of glass waste without sintering additives increases to 548 cycles. Researchers (Mačiulaitis, Malaiškienė 2010, 2012) determined that the use of sawdust (10.4-15.6\%) and crushed glass (6.4-9.6\%) results in porous and extremely frost resistant ceramics with the total open porosity reaching $40 \%$, and exploitative frost resistance of more than 300 cycles.
Researches conducted by Latvian scientists (Rozenstrauha et al. 2011) on the use of waste glass, mud and clay show that such samples have characteristics of sintered ceramics. In order to evaluate the suitable field of application, the following physical-mechanical properties of such samples were detected for novel glass-ceramic composites: bulk density, porosity and water uptake in the temperature range $1110-1140{ }^{\circ} \mathrm{C}$. The composition (containing $20 \mathrm{wt}$ \% waste glass, $20 \mathrm{wt}$. \% of sewage sludge and 60 wt. $\%$ of clay) with bulk density of $2.19 \mathrm{~g} / \mathrm{cm}^{3}$, water uptake of $2.5 \%$, porosity of $5 \%$, and compressive strength of $60.3 \pm 5.1 \mathrm{MPa}$, obtained at the temperature range $1130-1140{ }^{\circ} \mathrm{C}$ appeared to be the most perspective.

Authors (Balkyavichus et al. 2003) determined that the use of very finely ground glass waste lowers the temperature of liquid phase appearance. This suggests that melting glass reacts more intensively with clay because of the increased surface area of the reaction zone and the maximum degree of glass phase can influence the formation of new heat-resistant products, extend the range of sintering and stabilise sintering structure. According to the findings, the optimum amount of ground waste glass is $10 \%$. Then, the density of samples is approx. $2000 \mathrm{~kg} / \mathrm{m}^{3}$, compressive strength increases more than twice (about $40 \mathrm{MPa}$ ), and water absorption decreases to $6 \%$ or less. Scientists (Bernardo et al. 2006, 2007, 2010) analysed the influence of several different types of glass waste on the properties of ceramic samples Such types of waste decrease the sintering temperature from $1100{ }^{\circ} \mathrm{C}$ to $950{ }^{\circ} \mathrm{C}$. It was determined that the use of such types of waste and firing of samples at a relatively low temperature $\left(880-930{ }^{\circ} \mathrm{C}\right)$ for $1-3 \mathrm{~h}$ makes it possible to produce ceramic articles with compressive strength of $100 \mathrm{MPa}$ and density of $2600 \mathrm{~kg} / \mathrm{m}^{3}$. Additionally, it has been determined that the chemical composition and other characteristics of glass itself have a big influence on the characteristics of finished ceramic products.

The manuscript (Mueller et al. 2012) analysed possibilities to recycle various types of glass waste. It revealed that auto glass was not usable in the industry.

This article aims to determine possibilities to recycle processed auto glass waste in building ceramics, which could reduce solid waste pollution.

\section{Materials and research methods}

Researches focused on the use of the mixture of clay, non-plastics additives and minced crushed auto glass. The chemical composition of clay is given in Table 1. Granulometric composition of such clay is presented in Table 2. The chemical and granulometric compositions of this clay were determined using standard methods (LST EN 7255:2007; LST EN 1071-4:2002 and other). The clay was passed through a $0.63 \mathrm{~mm}$ sieve. 
Table 1. Average chemical composition of clay, wt. \%

\begin{tabular}{ccccccc}
\hline \multicolumn{7}{c}{ Average chemical composition of clay, wt. \% } \\
\hline $\mathrm{SiO}_{2}$ & $\mathrm{Al}_{2} \mathrm{O}_{3}+\mathrm{TiO}_{2}$ & $\mathrm{Fe}_{2} \mathrm{O}_{3}$ & $\mathrm{CaO}$ & $\mathrm{MgO}$ & $\mathrm{K}_{2} \mathrm{O}$ & L.O.I. \\
66.33 & 15.80 & 6.42 & 1.80 & 2.72 & 1.63 & 05.30 \\
\hline
\end{tabular}

Table 2. Granulometric composition of clay, wt. \%

\begin{tabular}{cccccccccc}
\hline \multicolumn{10}{c}{ Average elemental chemical composition of glass, wt. \% } \\
\hline $\mathrm{C}$ & $\mathrm{O}_{2}$ & $\mathrm{Na}$ & $\mathrm{Ca}$ & $\mathrm{Mg}$ & $\mathrm{K}$ & $\mathrm{Al}$ & $\mathrm{Si}$ & $\mathrm{Fe}$ \\
2.72 & 52.06 & 6.85 & 6.45 & 1.76 & 0.38 & 0.48 & 28.14 & 1.16 \\
\hline
\end{tabular}

Table 3. Average chemical composition of glass, wt. \%

\begin{tabular}{cccccccccc}
\hline \multicolumn{10}{c}{ Average elemental chemical composition of glass, wt. \% } \\
\hline $\mathrm{C}$ & $\mathrm{O}_{2}$ & $\mathrm{Na}$ & $\mathrm{Ca}$ & $\mathrm{Mg}$ & $\mathrm{K}$ & $\mathrm{Al}$ & $\mathrm{Si}$ & $\mathrm{Fe}$ \\
2.72 & 52.06 & 6.85 & 6.45 & 1.76 & 0.38 & 0.48 & 28.14 & 1.16 \\
\hline
\end{tabular}

Ground auto glass was used in the researches as the additive fluxing the clay mass.

This glass has a distinguishing characteristic, namely, it contains a sintering component. The elemental

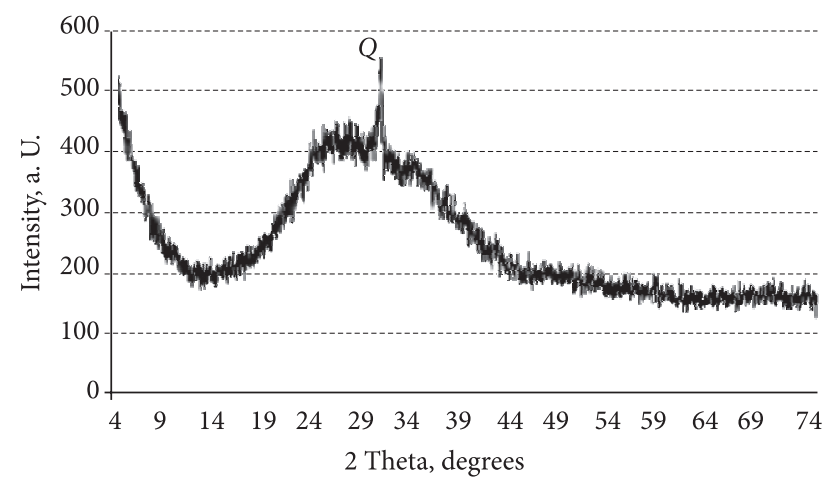

Fig. 1. X-ray diagram of auto glass

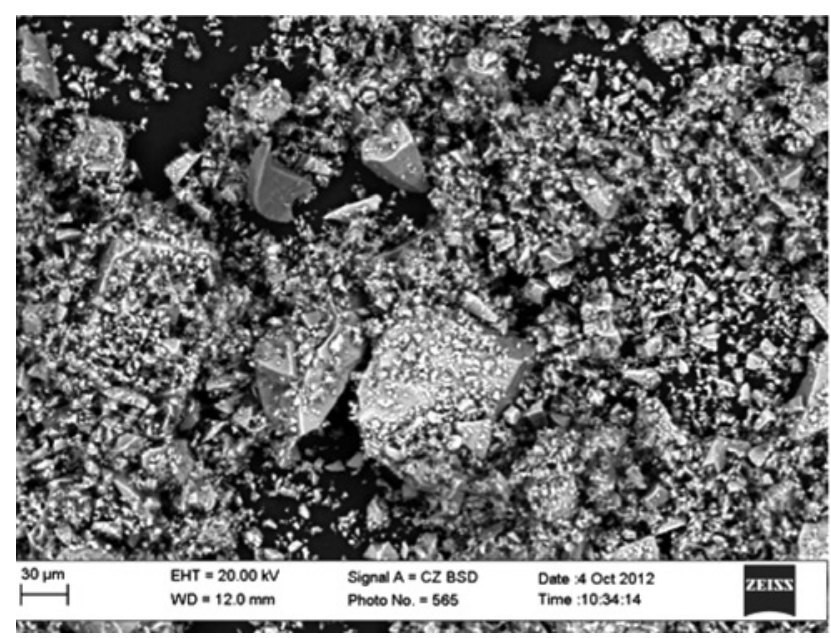

a) chemical composition of glass is given in Table 3 and the $\mathrm{X}$-ray structural analysis is shown in Fig. 1. According to the data in Table 3, no hazardous substances were found in the chemical composition of auto glass. The data in Fig. 1 show that the main mineral of used glass is Quartz $Q(0.335 \mathrm{~nm})$; also, there is some amorphous phase.

The image of used ground glass waste microstructure is presented in Fig. 2.

The microstructure shows that the size of auto waste glass particles varies from 1 to $70 \mu \mathrm{m}$, the particles are irregularly shaped and the finest particles are stuck together. However, mixed with clay and non-plastics additives, the particles separate and evenly distribute in the mixture

As presented in Table 4, compositions of ceramic mixtures from these raw materials were selected. The amount of waste was selected from other research results as well as results of researches on various types of waste

Fig. 2. Image of ground glass waste microstructure: a - (magnified 400 times); b - (magnified 2500 times) 
conducted by the article authors (Malaiškienè et al. 2011). The amount of waste was not busted, because of small glass particle formation on the surface of ceramics. Increasing the amount of waste to $20 \%$, a significant amount of glass grains are produced on the surface, which is undesirable.

Table 4. Compositions of ceramic mixtures

\begin{tabular}{ccc}
\hline Mixture & $\begin{array}{c}\text { Mixture of clay } \\
\text { and non-plastic } \\
\text { additive, } \%\end{array}$ & $\begin{array}{c}\text { Auto glass waste, } \\
\%\end{array}$ \\
\hline S1 & 100 & 0 \\
S2 & 95 & 5 \\
S3 & 90 & 10 \\
S4 & 85 & 15 \\
\hline
\end{tabular}

The non-plastic additive is quartz sand (10\%), fraction $0 / 1$.

Formed samples $(50 \times 50 \times 50 \mathrm{~mm})$ were dried for 3 days under normal laboratory conditions. Later, they were dried to constant weight in the laboratory oven at $105{ }^{\circ} \mathrm{C}$. After drying, the samples were burnt at three different temperatures: $1000{ }^{\circ} \mathrm{C}$ (temperature rise rate is $1.04{ }^{\circ} \mathrm{C} / \mathrm{min}$, maintaining at the maximum temperature for $4 \mathrm{~h}$, the temperature decrease rate is $1.11^{\circ} \mathrm{C} / \mathrm{min}$ ), $1050{ }^{\circ} \mathrm{C}$ (temperature rise rate is $1.09{ }^{\circ} \mathrm{C} / \mathrm{min}$, maintaining at the maximum temperature for $4 \mathrm{~h}$, the temperature decrease rate is $1.17{ }^{\circ} \mathrm{C} / \mathrm{min}$ ) and $1080{ }^{\circ} \mathrm{C}$ (temperature rise rate of is $1.13{ }^{\circ} \mathrm{C} / \mathrm{min}$, maintaining at the maximum temperature for $4 \mathrm{~h}$, the temperature decrease rate is $1.12^{\circ} \mathrm{C} / \mathrm{min}$ ). Temperature decreases to $400{ }^{\circ} \mathrm{C}$ in accordance with the set program. Later, the decrease of temperature slows down. The burning temperature was chosen according to the literature and earlier results. The burning temperature was not higher; samples lost their form because of a higher temperature.

The sintered and cooled samples were used to determine the physical-mechanical and structural parameters and forecasted frost resistance according to Table 5 (Mačiulaitis, Malaiškienè 2012). The analysis of glass

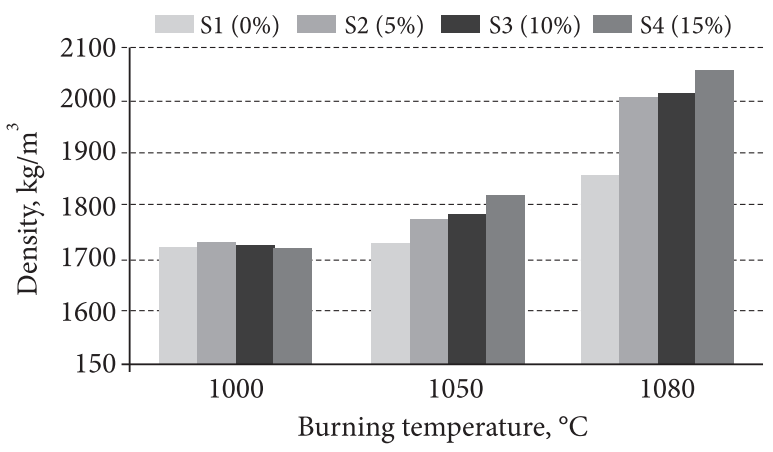

Fig. 3. Density of the samples powder was performed with the help of XRD. The main instrument used was the diffractometer DRON-7; a cobalt anode was used (the wavelength of $\lambda=0.1792 \mathrm{~nm}$ ). The micro-structural analysis of car glass waste was performed using the microscope Carl Zeis Evo LS 25. The parameters of net dry density and water absorption of ceramic samples were determined in accordance with standards LST EN 772-13:2003 and LST EN 771-1+A1, and compressive strength - LST EN 772-1.

To determine whether the change in compressive strength was only determined by the change in density, the strength was recalculated based on the constant density selected from literature (Laukaitis, Sinica 2006):

$$
R_{g n}=\frac{R_{\text {gneks }} \cdot \rho_{s k}^{2}}{\rho_{e k s}^{2}},
$$

where: $R_{g n}$ - compressive strength, when density is $1850 \mathrm{~kg} / \mathrm{m}^{3}, \mathrm{MPa} ; R_{\text {gneks }}$ - experimental compressive strength, $\mathrm{MPa} ; \rho_{\text {eks }}$ - experimental density, $\mathrm{kg} / \mathrm{m}^{3}, \rho_{s k}-$ estimated ceramic density $1850 \mathrm{~kg} / \mathrm{m}^{3}$.

\section{Research results and analysis}

The average values of parameters are presented in the discussion of obtained results. The obtained density results are presented in Fig. 3.

The data of Fig. 3 show that the increase of density in ceramics is highly dependent on the burning temperature. Due to the ongoing sintering processes, the higher is the temperature, the thicker are the samples. The temperature of $1080{ }^{\circ} \mathrm{C}$ is sufficient in order to get the density higher than $2000 \mathrm{~kg} / \mathrm{m}^{3}$. The samples of batches S2-S4 had a much higher density compared to the control samples without the additive of glass. Therefore, the additive of ground auto glass acts as a flux (which stimulates sintering) and increases the density of samples. Subsequent to analysis of the samples burnt at the temperature of $1080{ }^{\circ} \mathrm{C}$, a large difference in density was determined between samples that did not have the fluxing additive and contained $15 \%$ of ground auto glass, accordingly $1860 \mathrm{~kg} / \mathrm{m}^{3}$ and $2060 \mathrm{~kg} / \mathrm{m}^{3}$. Such an increase in density is associated with melting of ground auto glass particles at a higher temperature, which results in thicker structure and reduced volume of pores in the sample.

The results regarding the general contraction of ceramics are given in Fig. 4. According to the data, the general contraction increases with the increasing amount of glass waste. Besides, as the general contraction increases, the burning temperature becomes higher. Such effect could be explained by a higher sintering rate. Higher burning temperature and milled glass additive promotes sintering processes.

One of the most important characteristics of ceramics is water absorption. Water absorption, effective and 
Table 5. The methodology for forecasting frost resistance according to structural parameters (Mačiulaitis, Malaiškienė 2012)

\begin{tabular}{|c|c|c|c|}
\hline $\begin{array}{l}\text { Description } \\
\text { of the basic } \\
\text { parameter } \\
\text { and units of }\end{array}$ & Physical meaning of parameters & $\begin{array}{l}\text { Calculation } \\
\text { formulas }\end{array}$ & $\begin{array}{l}\text { Description of partial values } \\
\text { and units of measurement }\end{array}$ \\
\hline
\end{tabular}
measurement

\begin{tabular}{|c|c|c|c|c|c|}
\hline $\begin{array}{l}\text { Reserve of pore } \\
\text { volume } R, \%\end{array}$ & $\begin{array}{l}\text { Reserve of pore volume defines the } \\
\text { quantity of reserve pores and capillaries, } \\
\text { to which water or plastic ice penetrate } \\
\text { very hardly. The bigger is the reserve } \\
\text { of pore volume, the bigger is the } \\
\text { exploitation frost resistance of ceramics. }\end{array}$ & $R=$ & $\left.1-\frac{W_{e}}{W_{p}}\right)$ & $\cdot 100$ & $\begin{array}{l}W_{e}-\text { effective porosity from water absorption } \\
\text { after } 72 \mathrm{~h}, \% \text {; } \\
W_{p}-\text { total open porosity from water } \\
\text { absorption in the vacuum process (special } \\
\text { regime), \%. }\end{array}$ \\
\hline
\end{tabular}

\begin{tabular}{|c|c|c|c|}
\hline $\begin{array}{l}\text { Effective } \\
\text { porosity of } \\
\text { ceramic body } \\
W_{\rho}, \%\end{array}$ & $\begin{array}{l}\text { Effective porosity of ceramic body } \\
\text { defines the amount of effectively working } \\
\text { pores and capillaries. }\end{array}$ & $W_{e}=\rho \frac{m_{1}-m}{m} \cdot 100$ & $\begin{array}{l}m \text { - mass of the sample dried up to the } \\
\text { constant weight, } \mathrm{g} \text {; } \\
m_{1} \text { - mass of the saturated sample, } \mathrm{g} \text {; } \\
\rho \text { - density of the sample, } \mathrm{g} / \mathrm{cm}^{3} \text {. }\end{array}$ \\
\hline
\end{tabular}
Total open Total open porosity defines the total porosity $W_{p}, \%$ open porous space of ceramic body in the macrostructure and microstructure dimension.

$$
\begin{aligned}
& m \text { - mass of the sample dried up to the } \\
& \text { constant weight, } \mathrm{g} \text {; } \\
& \rho \text { - density of the sample, } \mathrm{g} / \mathrm{cm}^{3} \text {. }
\end{aligned}
$$

\begin{tabular}{|c|c|c|c|}
\hline $\begin{array}{l}\text { Qualified } \\
\text { thickness of the } \\
\text { wall of pores } \\
\text { and capillaries } \\
D, \%\end{array}$ & $\begin{array}{l}\text { This parameter defines qualified thickness } \\
\text { of the wall of pores and capillaries. The } \\
\text { greater is the thickness of the wall of } \\
\text { pores and capillaries, the greater is the } \\
\text { exploitation frost resistance of products. }\end{array}$ & $D=\frac{100-W_{p}}{W_{p}}$, & $\begin{array}{l}W_{p} \text { - total open porosity from water } \\
\text { absorption in the vacuum process (special } \\
\text { regime), } \% .\end{array}$ \\
\hline $\begin{array}{l}\text { Degree of } \\
\text { structural } \\
\text { inhomogeneity } \\
N_{H} \text { units }\end{array}$ & $\begin{array}{l}\text { Degree of structural inhomogeneity } \\
\text { enables to evaluate the structural } \\
\text { inhomogeneity of effective capillaries } \\
\text { according to their equivalent length. }\end{array}$ & $N_{H}=\frac{H_{\max }-H_{\min }}{H_{\min }}$ & $\begin{array}{l}H_{\text {max }}, H_{\text {min }} \text { - rates of capillary wetting front } \\
\text { (after } 5 \mathrm{~min} \text { ), mm. }\end{array}$ \\
\hline $\begin{array}{l}\text { Capillary rate } \\
\text { of mass flow } g_{1} \text {, } \\
\mathrm{g} / \mathrm{cm}^{2}\end{array}$ & $\begin{array}{l}\text { Capillary rate of mass flow indicates the } \\
\text { equivalent diameter of capillaries. These } \\
\text { parameters detail the anisotropy of pores } \\
\text { and capillaries. }\end{array}$ & $g_{1}=\frac{m_{3}-m}{S}$ & $\begin{array}{l}m_{3}-\text { mass of the sample saturated by the } \\
\text { capillary suction process (after } 30 \text { min), g; } \\
m \text { - mass of the sample dried up to the } \\
\text { constant weight, g; } \\
S \text { - surface area of the sample, } \mathrm{cm}^{2} .\end{array}$ \\
\hline $\begin{array}{l}\text { Capillary rate } \\
\text { of mass flow in } \\
\text { a vacuum in the } \\
\text { direction } \\
\text { of freezing } G_{1} \text {, } \\
\mathrm{g} / \mathrm{cm}^{2}\end{array}$ & & $G_{1}=\frac{m_{4}-m}{S}$ & $\begin{array}{l}m_{4}-\text { mass of the sample which is being } \\
\text { saturated for } 10 \text { min by capillary suction } \\
\text { in a vacuum as saturation goes through } \\
\text { the plane which is being frozen under } \\
\text { exploitation, } g \text {; } \\
m \text { - mass of the sample dried up to the } \\
\text { constant weight, } g \text {. }\end{array}$ \\
\hline $\begin{array}{l}\text { Capillary rate } \\
\text { of mass flow } \\
\text { in a vacuum } \\
\text { in a vertical } \\
\text { direction to } \\
\text { freezing } G_{2} \\
\mathrm{~g} / \mathrm{cm}^{2}\end{array}$ & & $G_{2}=\frac{m_{5}-m}{S}$ & $\begin{array}{l}m_{5}-\text { mass of the sample which is being } \\
\text { saturated for } 10 \text { min by capillary suction } \\
\text { in a vacuum as saturation goes through the } \\
\text { plane which is vertical to the freezing plane } \\
\text { under exploitation, g; } \\
m \text { - mass of the sample dried up to the } \\
\text { constant weight, g. }\end{array}$ \\
\hline
\end{tabular}$$
W_{p}=\rho \frac{m_{2}-m}{100} \begin{aligned}
& m_{2}-\text { mass of the sample saturated using the } \\
& \text { vacuum process in air, } g ;
\end{aligned}
$$

$\begin{aligned} & \text { The beginning } \\ & \text { of destruction, } \\ & \text { cycles }\end{aligned} \quad F_{R E 1}=0.231 \frac{R^{1.068} D^{1.345} G_{1}^{0.275} G_{2}^{0.663}}{N^{0.285} g_{1}^{0.830}}$


total open porosity of the samples determined during the researches are presented in Figs 5-7.

The difference in porosity of the samples burnt at the same temperature is insignificant. Burning temperature has the main influence on water absorption and porosity. The lowest water absorption (determined after $72 \mathrm{~h}$ ) of $1.2 \%$, the effective and total open porosity were characteristic to samples of the batch S4 (the amount of glass waste in formation mixture was $15 \%$ ), which were burnt at the highest temperature of $1080{ }^{\circ} \mathrm{C}$. This was affected not only by the highest sintering temperature, but also by

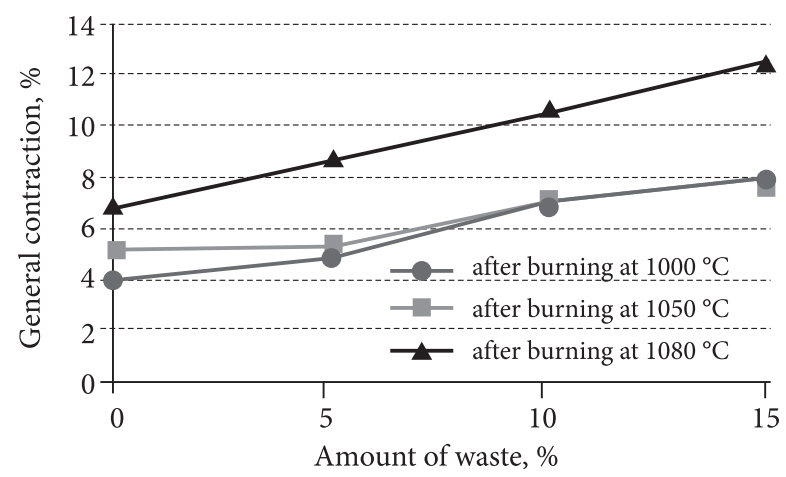

Fig. 4. General contraction of the samples

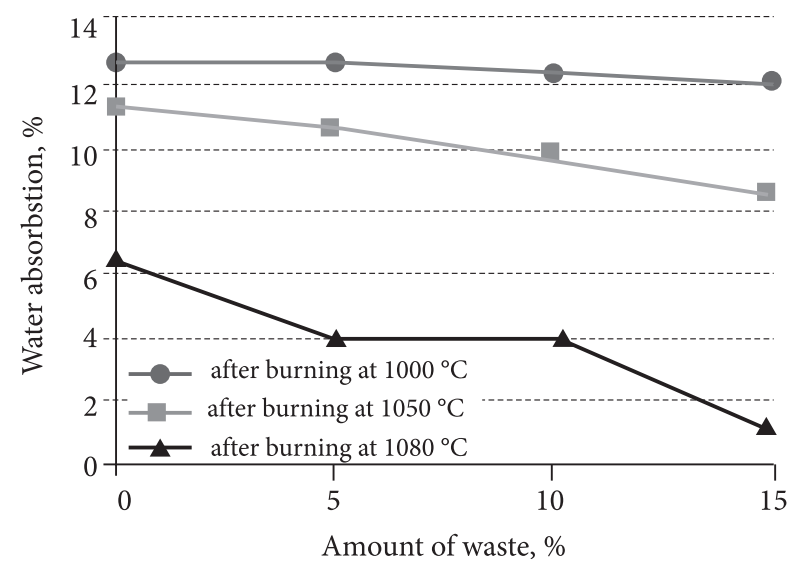

Fig. 5. Influence of the amount of waste on water absorption

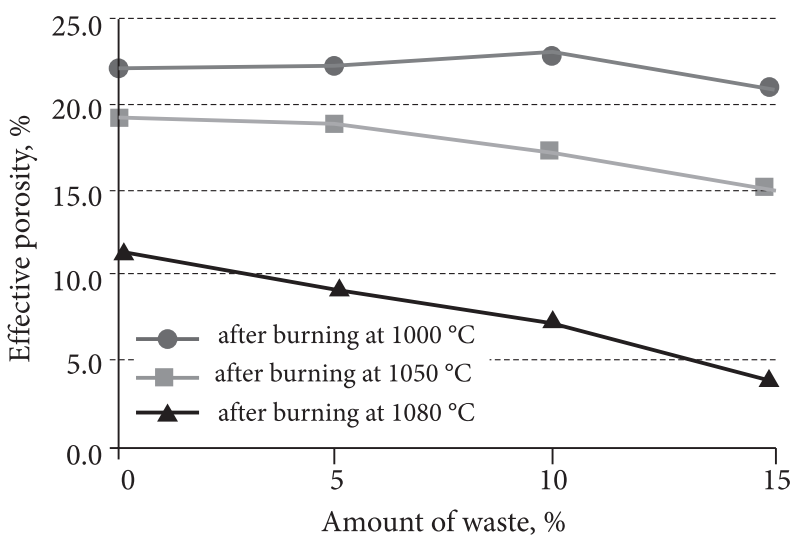

Fig. 6. Influence of the amount of waste on effective porosity ground auto glass, as this additive melted during the burning process resulting in the structure of more closed pores and capillaries.

The results of the compressive strength of ceramics are presented in Fig. 8.

According to the results of compressive strength obtained through the research, the increase in the burning temperature results in the increase of the compressive strength due to the decrease in the porosity of the sample. However, investigations on the influence of the amount of waste produced some very interesting results. Once the samples were burnt at temperatures of $1000{ }^{\circ} \mathrm{C}$ and $1050{ }^{\circ} \mathrm{C}$, it was determined that the compressive strength of samples with 5 and $10 \%$ glass waste was lower compared to samples without this additive. Addition of $15 \%$ of ground auto glass to the formation mixture increased the compressive strength to $9-14 \%$ in comparison to the control samples. This phenomenon can be explained by small amounts of glass and low burning temperature, which is insufficient for the glass to start melting and forming new combinations. A larger amount of glass reacts with clay particles faster and forms new combinations.

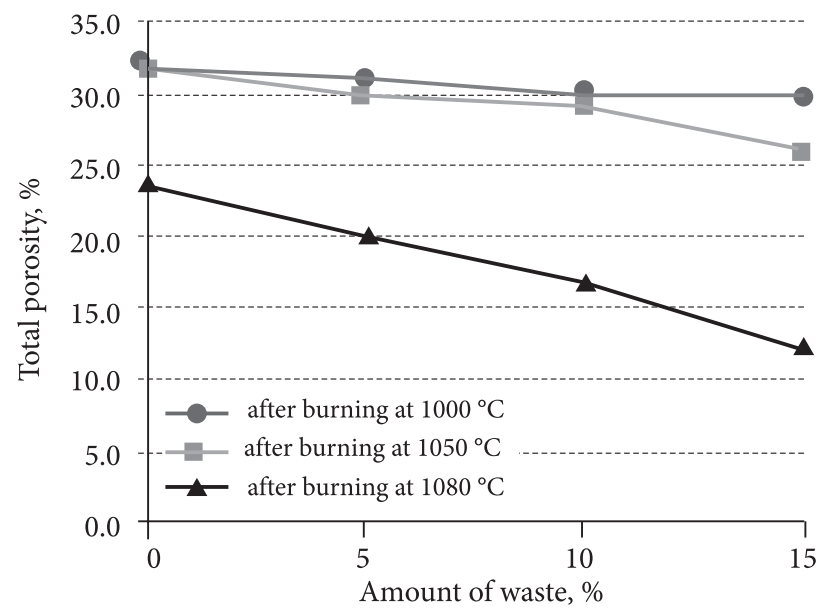

Fig. 7. Influence of the amount of waste on the total open porosity

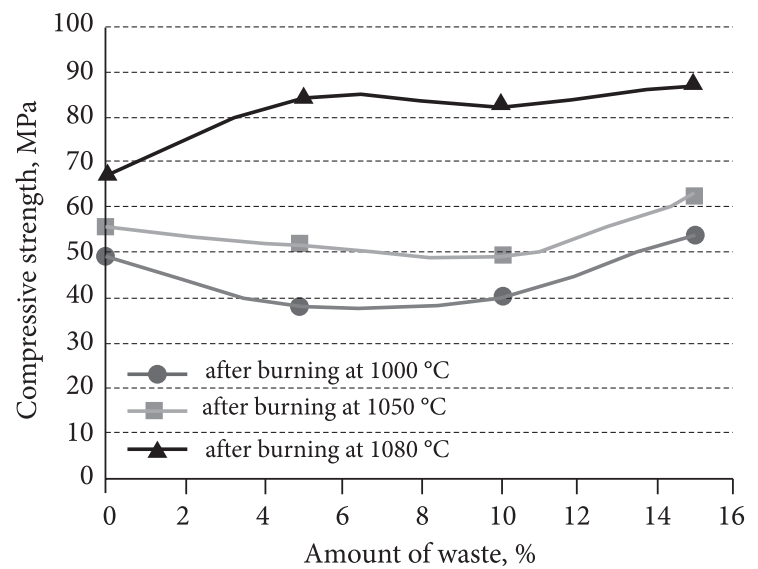

Fig. 8. The results of compressive strength 
Results recalculated by the same density $\left(1850 \mathrm{~kg} / \mathrm{m}^{3}\right)$ compressive strength (Laukaitis, Sinica 2006) are given in Fig. 9.

Figs 8 and 9 demonstrate similar persisting variation tendencies of compressive strength, which varied up to $20 \%$. Consequently, the change of the compressive strength not only depends on change in density, but also on the amount of waste.

Sufficiently high compressive strength values were determined in small size samples of $50 \times 50 \times 50 \mathrm{~mm}$, as such samples resulted in fewer defects.

The values of examined structural parameters, by which frost resistance is forecasted, are presented in Table 6 . The capillary mass flow rate of the samples decreases with the increase in the burning temperature and the amount of ground auto glass, while the reserve of pore space and the relative thickness of pores and capillaries increase significantly. According to the results of structural parameters, it is possible to assume that in this case, samples with $15 \%$ of auto glass waste burnt at the temperature of $1080{ }^{\circ} \mathrm{C}$ would have the highest frost resistance.

The forecasted frost resistance of the samples is presented in Table 7.

According to calculation results, the maximum frost resistance (when the beginning of destruction reaches 1343 cycles and the end of decomposition is at 2188 cycles) is particular to samples that contain $15 \%$ of ground

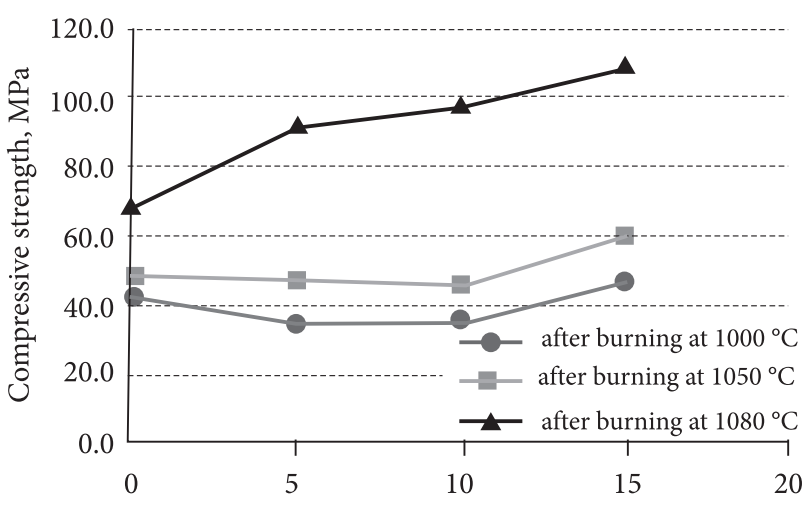

Amount of waste, $\%$

Fig. 9. The results of compressive strength, when density is $1850 \mathrm{~kg} / \mathrm{m} 3$

auto glass waste in the formation mixture and burnt at the temperature of $1080{ }^{\circ} \mathrm{C}$.

Such significant increase in frost resistance as a parameter was predetermined by sufficient burning temperature and the maximum amount of fluxing additive. The glass melted at the temperature of $1080{ }^{\circ} \mathrm{C}$, which decreased the amount of open pores and defects in the sample. As there is a little amount of burning additive in auto glass, it produces a large number of small pores, which is filled completely or partially with glass melted at sufficiently high burning temperature. Then, the relative thickness of pores and capillaries and the reserve of

Table 6. Average values of the derivatives of structural parameters

\begin{tabular}{|c|c|c|c|c|c|c|}
\hline Mixture & $R, \%$ & $D, \%$ & $G_{1}, \mathrm{~g} / \mathrm{cm}^{2}$ & $G_{2}, \mathrm{~g} / \mathrm{cm}^{2}$ & $\mathrm{~g}, \mathrm{~g} / \mathrm{cm}^{2}$ & $N$, units \\
\hline \multicolumn{7}{|c|}{ The highest burning temperature $1000{ }^{\circ} \mathrm{C}$} \\
\hline $\mathrm{S} 1(0 \%)$ & 28.61 & 2.2 & 0.59 & 0.52 & 0.98 & 0.250 \\
\hline $\mathrm{S} 2(5 \%)$ & 26.87 & 2.2 & 0.54 & 0.60 & 1.03 & 0.558 \\
\hline $\mathrm{S} 3(10 \%)$ & 27.64 & 2.1 & 0.67 & 0.59 & 1.01 & 0.260 \\
\hline $\mathrm{S} 4(15 \%)$ & 28.09 & 2.4 & 0.71 & 0.69 & 1.25 & 0.241 \\
\hline \multicolumn{7}{|c|}{ The highest burning temperature $1050^{\circ} \mathrm{C}$} \\
\hline $\mathrm{S} 1(0 \%)$ & 38.32 & 2.2 & 0.522 & 0.550 & 0.78 & 0.485 \\
\hline $\mathrm{S} 2(5 \%)$ & 34.91 & 2.4 & 0.517 & 0.513 & 0.81 & 0.277 \\
\hline $\mathrm{S} 3(10 \%)$ & 42.14 & 2.4 & 0.486 & 0.546 & 0.68 & 0.265 \\
\hline S4(15\%) & 40.34 & 2.9 & 0.402 & 0.431 & 0.61 & 0.514 \\
\hline \multicolumn{7}{|c|}{ The highest burning temperature $1080^{\circ} \mathrm{C}$} \\
\hline $\mathrm{S} 1(0 \%)$ & 49.22 & 3.6 & 0.174 & 0.239 & 0.24 & 0.579 \\
\hline $\mathrm{S} 2(5 \%)$ & 55.88 & 4.5 & 0.081 & 0.094 & 0.05 & 1.16 \\
\hline $\mathrm{S} 3(10 \%)$ & 54.45 & 4.9 & 0.187 & 0.245 & 0.05 & 0.692 \\
\hline $\mathrm{S} 4(15 \%)$ & 66.85 & 7.1 & 0.087 & 0.110 & 0.02 & 0.316 \\
\hline
\end{tabular}

$R$ - reserve of porous volume, $\% ; D$ - relative thickness of the wall of pores and capillaries; $G_{1}$ - capillary mass flow rate in a vacuum in the direction of cooling, $\mathrm{g} / \mathrm{cm}^{2} ; G_{2}$ - capillary mass flow rate in a vacuum perpendicular to the direction of cooling, $\mathrm{g} / \mathrm{cm}^{2} ; \mathrm{g}-\mathrm{capil}^{-}$ lary mass flow rate determined under normal conditions, $\mathrm{g} / \mathrm{cm}^{2} ; N$ - structural inhomogeneity, units. 
Table 7. The forecasted frost resistance of the samples

\begin{tabular}{|c|c|c|c|c|c|c|}
\hline \multirow[t]{2}{*}{ Mixture } & $\begin{array}{c}\text { The } \\
\text { beginning of } \\
\text { decomposition, } \\
\text { in cycles }\end{array}$ & $\begin{array}{l}\text { The end of } \\
\text { decomposition, } \\
\text { in cycles }\end{array}$ & $\begin{array}{c}\text { The } \\
\text { beginning of } \\
\text { decomposition, } \\
\text { in cycles }\end{array}$ & $\begin{array}{l}\text { The end of } \\
\text { decomposition, } \\
\text { in cycles }\end{array}$ & $\begin{array}{c}\text { The } \\
\text { beginning of } \\
\text { decomposition, } \\
\text { in cycles }\end{array}$ & $\begin{array}{l}\text { The end of } \\
\text { decomposition, } \\
\text { in cycles }\end{array}$ \\
\hline & \multicolumn{2}{|c|}{$1000^{\circ} \mathrm{C}$} & \multicolumn{2}{|c|}{$1050^{\circ} \mathrm{C}$} & \multicolumn{2}{|c|}{$1080^{\circ} \mathrm{C}$} \\
\hline $\mathrm{S} 1(0 \%)$ & 21 & 33 & 28 & 58 & 81 & 145 \\
\hline S (5\%) & 16 & 28 & 31 & 54 & 204 & 353 \\
\hline $\mathrm{S} 3(10 \%)$ & 20 & 34 & 47 & 90 & 203 & 406 \\
\hline $\mathrm{S} 4(15 \%)$ & 23 & 37 & 40 & 71 & 1343 & 2188 \\
\hline
\end{tabular}

pore space increase, while open porosity, water absorption and capillary mass flow rate decrease. Such a change of structural parameters causes a very high frost resistance and compressive strength.

\section{Conclusions}

It was determined that ground auto glass waste can be successfully used in the production of sintered ceramics. The optimum amount of waste in formation mixture is $15 \%$, the burning temperature is $1080{ }^{\circ} \mathrm{C}$ for the duration of $4 \mathrm{~h}$. The water absorption of such ceramics amounts to $1.2 \%$, and the forecasted frost resistance at the start of decomposition is 1343 cycles and at the end of decomposition it amounts to 2188 .

1. Addition of $15 \%$ of ground glass into formation mixture and burning of samples at $1080{ }^{\circ} \mathrm{C}$ reduces the porosity of the samples by approx. $50 \%$ and increases the compressive strength by $14 \%$, density by $10 \%$ and the reserve of pore space by $36 \%$.

2. Compressive strength largely depends on the amount of ground auto glass in the formation mixture ( $R=0.858-0.998)$. Burning samples at the temperature equal or below $1050{ }^{\circ} \mathrm{C}$, compressive strength varies parabolically depending on the amount of waste used; burning of samples at the temperature of $1080{ }^{\circ} \mathrm{C}$, the compressive strength starts to increase exponentially with the increasing amount of glass in the mixture.

\section{References}

Angjusheva, B. 2011. Production and characterization of glassceramics from waste materials, Quality of Life 2(1-2): 13-20.

Balkyavichus, V.; Valyukyavichus, Ch.; Shpokauskas, A.; Laukaitis, A.; Pyatrikaitis, F. 2003. Sinterability of low-melting Illite-Bearing Clays, Glass and Ceramics 6: 18-21.

Bernardo, E.; Bonomo, E.; Dattoli, A. 2010. Optimisation of sintered glass-ceramics from an industrial waste glass, $\mathrm{Ce}$ ramics International 36: 1675-1680. http://dx.doi.org/10.1016/j.ceramint.2010.02.047

Bernardo, E.; Castellan, R.; Hreglich, S. 2007. Sintered glassceramics from mixtures of wastes, Ceramics International 33: 27-33. http://dx.doi.org/10.1016/j.ceramint.2005.07.012
Bernardo, E.; Castellan, R.; Hreglich, S.; Lancellotti, I. 2006. Sintered sanidine glass-ceramics from industrial wastes, Journal of the European Ceramic Society 26: 3335-3341. http://dx.doi.org/10.1016/j.jeurceramsoc.2005.09.110

Chiang, K-Y.; Chen, Y-C.; Chien, K-L. 2010. Scrap glass effect on building materials characteristics manufactured from water treatment plant sludge, Environmental Engineering Science 27(2): 137-145. http://dx.doi.org/10.1089/ ees.2009.0036

Dhaliwal, A. K.; Hay, J. N. 2002. The characterization of polyvinyl butyral by thermal analysis, Thernochimica Acta 391: 245-255. http://dx.doi.org/10.1016/S0040-6031(02)00187-9

Dondi, M.; Guarini, G.; Raimondo, M.; Zanelli, C. 2009. Recycling PC and TV waste glass in clay bricks and roof tiles, Waste Management 29: 1945-1951. http://dx.doi.org/10.1016/j.wasman.2008.12.003

Gorokhovsky, A. V.; Escalante-Garcia, J. I.; Gashnikova, G. Yu.; Nikulina, L. P.; Artemenko, S. E. 2005. Composite materials based on wastes of flat glass processing, Waste Management 25: 733-736. http://dx.doi.org/10.1016/j.wasman.2004.11.007

Jaw, K.-S.; Hsu, C.-K.; Lee, J.-S. 2001. The thermal decomposition behaviors of stearic acid, paraffin wax and polyvinyl butyral, Thermochimica Acta 367-368: 165-168. http://dx.doi.org/10.1016/S0040-6031(00)00680-8

Kabanov, V. A.; Akutin, N. M.; Bakejev, S. F.; Vonskij, E. V.; Evstratov, B. F.; Enikolopen, N. S.; Smirnov, V. V.; Slonimskij, G. L.; Frenkel, S. J.; Jakubovič, S. B. 1974. Encyclopaedia of polymers. Editorial board. Moskow: Soviet encyclopaedia. 1032 p. (in Russian).

Kourti, I.; Amutha, D. R.; Deegan, D.; Boccaccini, A. R.; Cheeseman, C. R. 2010. Production of geopolymers using glass produced from DC plasma treatment of air pollution control (APC) residues, Journal of Hazardous Materials 176: 704-709. http://dx.doi.org/10.1016/j.jhazmat.2009.11.089

Laukaitis, A.; Sinica, M. 2006. Non-autoclaved porous concrete and its composite products. Monograph. Vilnius: Technika. 235 p. (in Lithuanian).

Lin, K.-L.; Huang, L.-S.; Shie, J.-L.; Cheng, C.-J.; Lee, C.-H.; Chang, T.-C. 2012. Elucidating the effects of solar panel waste glass substitution on the physical and mechanical characteristics of clay bricks, Environmental Technology 1: $1-10$.

LST EN 725-5. 2007. Advanced technical ceramics - Methods of test for ceramic powders - Part 5: Determination of particle size distribution. Vilnius: Lithuanian Standards Board. 15 p. 
LST EN 1071-4. 2002. Advanced technical ceramics - Methods of test for ceramic coatings - Part 4: Determination of chemical composition. Vilnius: Lithuanian Standards Board. $15 \mathrm{p}$.

LST EN 772-13. 2003. Methods of test for masonry units Part 13: Determination of net and gross dry density of masonry units (except for natural stone). Vilnius: Lithuanian Standards Board. $8 \mathrm{p}$.

LST EN 772-1. 2003. Methods of test for masonry units Part 1: Determination of compressive strength. Vilnius: Lithuanian Standards Board. $11 \mathrm{p}$.

LST EN 771-1+A1:2005. Methods of test for masonry units. Part 1. Ceramic masonry products. Vilnius: Lithuanian Standards Board. $44 \mathrm{p}$.

Mačiulaitis, R.; Malaiškienė, J. 2010. Frost resistant porous ceramics, Materials Science (Medžiagotyra) 16(4): 359-364.

Mačiulaitis, R.; Malaiškienè, J. 2012. Possibilities of controlling properties and technological parameters of building ceramics. Vilnius: Technika. $184 \mathrm{p}$.

Malaiškienė, J.; Vaičienè, M.; Žurauskienè, R. 2011. Effectiveness of technogenic waste usage in products of building ceramics and expanded clay concrete, Construction and Building Materials 25(10): 3869-3877.

http://dx.doi.org/10.1016/j.conbuildmat.2011.04.008

Mueller, J. R.; Boehm, M. W.; Drummond, C. 2012. Direction of CRT waste glass processing: electronics recycling industry communication, Waste Management 32(8): 1560-1565. http://dx.doi.org/10.1016/j.wasman.2012.03.004
Pavlushkina, T. K.; Kisilenko, N. G. 2011. Cullet use in the production of building materials, Glass and Ceramics 68(56): 162-168. http://dx.doi.org/10.1007/s10717-011-9346-4

Roether, J. A.; Daniel, D. J.; Amutha Rani, D.; Deegan, D. E.; Cheeseman, C. R.; Boccaccini, A. R. 2010. Properties of sintered glass-ceramics prepared from plasma vitrified air pollution control residues, Journal of Hazardous Materials 173: 563-569. http://dx.doi.org/10.1016/j.jhazmat.2009.08.123

Rozenstrauha, I.; Sosins, G.; Petersone, L.; Krage, L.; Drille, M.; Filipenkov, V. 2011. Production of glass-ceramics from sewage sludge and waste glass [online], [cited 20 September 2012], in 5th Baltic Conference on Silicate Materials, Materials Science and Engineering 25. Available from Internet: http://iopscience.iop.org/1757-899X/25/1/012016/pdf/1757899X_25_1_012016.pdf

Seo, J. J.; Kuk, S. T.; Kim, K. 1997. Thermal decomposition of PVB (polyvinyl butyral) binder in the matrix and electrolyte of molten carbonate fuel cells, Journal of Power Sources 69: 61-68. http://dx.doi.org/10.1016/S0378-7753(97)02570-6

Uselytė, R.; Silvestravičiūtè, I.; Karaliūnaite, I. 2007. Atlieku panaudojimo naujiems produktams gaminti ir šiu produktu iteisinimo galimybiu studija (The possibilities study of waste usage for new products and products validation) [online], [cited 18 October 2012]. 89 p. Available from Internet: http://aurimas.ukmin.dev5.kryptis.lt/uploads/documents/imported/lt/veikla/veiklos_sritys/pramone_ir_verslas/reglamentavimas/mokslo\%20studijos/ekokonsultacijos_produktu_ iteisinimas_galutinis.pdf (in Lithuanian).

Jurgita MALAIŠKIENĖ. Doctor of Technological Sciences (Civil Engineering) and a Researcher at Vilnius Gediminas Technical University, the author and co-author of one study book and one educational book, 2 patents and more than 20 research articles. Research interests include creating and analysing physical, mechanical, structural, etc. properties and possibilities of using new conglomerates (ceramics, concrete, etc.) made of local recourses containing different forms of waste.

Romualdas MAČIULAITIS. Professor, Habilitated Doctor of Technological Sciences at Vilnius Gediminas Technical University, the author and co-author of 7 studies, 16 inventions, 3 patents, 15 educational books, 2 course books and more than 200 research articles. He assisted in training 12 Doctors of Technological Sciences, is a Member of the Editorial Board of the Journal of Civil Engineering and Management issued by VGTU and Lithuanian Academy of Sciences and the journal of Construction Science published by Riga Technical University (Latvia). He is an expert of the Research Council of Lithuania and a member of the Committee of PhD studies in the Engineering of Material Sciences (08T) at VGTU. Research interests include research into the exploitation frost resistance of ceramics and other wall building materials, producing long-life materials using recycled technogenic waste, analysing heat insulation materials, metallization of polymers, estimating the toxicity of heat insulation composites applied for roofing, combustibility prognostication, developing methodologies and investigating prognoses for reasons and resistance to fire in wooden buildings.

Raminta MIKALAUSKAITE் has a Master's Degree of the programme Construction Materials and Products at Vilnius Gediminas Technical University. 